\title{
Urotensin II Modulates Rapid Eye Movement Sleep through Activation of Brainstem Cholinergic Neurons
}

\author{
Salvador Huitron-Resendiz, ${ }^{1 \star}$ Morten P. Kristensen, ${ }^{4 \star}$ Manuel Sánchez-Alavez, ${ }^{1}$ Stewart D. Clark, ${ }^{5}$ Stephen L. Grupke, ${ }^{4}$ \\ Christopher Tyler, ${ }^{4}$ Chisa Suzuki, ${ }^{2}$ Hans-Peter Nothacker, ${ }^{3}$ Olivier Civelli, ${ }^{3}$ Jose R. Criado, ${ }^{1}$ Steven J. Henriksen, ${ }^{1}$ \\ Christopher S. Leonard, ${ }^{4}$ and Luis de Lecea ${ }^{1,2}$ \\ Departments of ${ }^{1}$ Neuropharmacology and ${ }^{2}$ Molecular Biology, The Scripps Research Institute, La Jolla, California 92037, ${ }^{3}$ Department of Pharmacology, \\ University of California, Irvine, Irvine, California 92697, ${ }^{4}$ Department of Physiology, New York Medical College, Valhalla, New York 10595, and ${ }^{5}$ The Centre \\ for Addiction and Mental Health, Toronto, Ontario, Canada M6J 1H4
}

Urotensin II (UII) is a cyclic neuropeptide with strong vasoconstrictive activity in the peripheral vasculature. UII receptor mRNA is also expressed in the CNS, in particular in cholinergic neurons located in the mesopontine tegmental area, including the pedunculopontine tegmental (PPT) and lateral dorsal tegmental nuclei. This distribution suggests that the UII system is involved in functions regulated by acetylcholine, such as the sleep-wake cycle. Here, we tested the hypothesis that UII influences cholinergic PPT neuron activity and alters rapid eye movement (REM) sleep patterns in rats. Local administration of UII into the PPT nucleus increases REM sleep without inducing changes in the cortical blood flow. Intracerebroventricular injection of UII enhances both REM sleep and wakefulness and reduces slow-wave sleep 2. Intracerebroventricular, but not local, administration of UII increases cortical blood flow. Moreover, whole-cell recordings from rat-brain slices show that UII selectively excites cholinergic PPT neurons via an inward current and membrane depolarization that were accompanied by membrane conductance decreases. This effect does not depend on action potential generation or fast synaptic transmission because it persisted in the presence of TTX and antagonists of ionotropic glutamate, GABA, and glycine receptors. Collectively, these results suggest that UII plays a role in the regulation of REM sleep independently of its cerebrovascular actions by directly activating cholinergic brainstem neurons.

Key words: urotensin II; REM sleep; urotensin receptors; acetylcholine; pedunculopontine tegmental nucleus; laterodorsal tegmental nucleus; cortical blood flow

\section{Introduction}

Urotensin II (UII) is a neuropeptide that was initially isolated from urophysis extracts of several species of fish (Pearson et al., 1980), with a core structure that is conserved through mollusks to mammals (Conlon et al., 1996, 1997; Chartrel et al., 1998; Coulouarn et al., 1998, 1999). UII has potent vasoconstrictor activity in the periphery (Russell et al., 2001; Bohm and Pernow, 2002). However, intracerebroventricular injection or intra-arterial injection of UII induces hypotensive and bradycardiac effects in rats (Gibson et al., 1986), suggesting that central UII plays a role in cardiovascular homeostasis through its specific receptor in blood vessels and in the CNS (Ames et al., 1999; Liu et al., 1999; Mori et al., 1999; Nothacker et al., 1999). Recent studies have shown that UII receptor mRNA colocalizes with choline acetyltransferase in the mesopontine tegmental area, including the pedunculopontine tegmental (PPT) and the lateral dorsal tegmental (LDT) nuclei (Clark et al., 2001).

The distribution of UII receptor mRNA in the cholinergic

Received Feb. 13, 2004; revised April 19, 2005; accepted April 20, 2005.

This work was supported in part by National Institutes of Health Grants MH58543 (L.d.L.), DA12444 and MH62261 (S.J.H.), MH68396 (H.P.N.), and HL64150 and NS27881 (C.S.L.).

*S.H.-R. and M.P.K. contributed equally to this work.

Correspondence should be addressed to Dr. Luis de Lecea, Department of Molecular Biology, MB-10, The Scripps Research Institute, 10550 North Torrey Pines Road, La Jolla, CA 92037. E-mail: llecea@scripps.edu. D0I:10.1523/JNEUROSCI.4501-04.2005

Copyright $\odot 2005$ Society for Neuroscience $\quad 0270-6474 / 05 / 255465-10 \$ 15.00 / 0$
PPT and LDT neurons suggests that, in addition to its vascular actions, the UII system may be involved in the regulation of the sleep-wake cycle. Previous studies in cats and rats have demonstrated the role of PPT and LDT nuclei in sleep regulation. The injection of cholinergic agonists into the medial pontine reticular formation, a target region of the PPT and LDT, induces a rapid eye movement (REM)-like state (George et al., 1964; Baghdoyan et al., 1984; Quattrochi et al., 1989; Bourgin et al., 1995) including cortical desynchronization, hippocampal theta rhythm, muscle atonia, reduction of REM sleep onset, and increase in total time of REM sleep (Vanni-Mercier et al., 1989; Yamamoto et al., 1990; Vertes et al., 1993). These and other studies (for review, see Steriade and McCarley, 1990) clearly indicate that cholinergic neurons in the PPT are important regulators of REM sleep.

Considering these studies and the observation that cholinergic PPT and LDT neurons express UII receptor mRNA, we tested the hypothesis that UII can significantly influence cholinergic PPT and LDT neuron activity and alter REM sleep patterns in rats. In addition, because UII induces changes in blood pressure (Gibson et al., 1986), and because it has been proposed that the hypnogenic properties of some putative sleep factors could be related to changes in blood pressure (Feinberg and Campbell, 1999), we also measured cortical blood flow $(\mathrm{CBF})$ in animals treated with UII.

Our results show that both local injection of UII $(0.6 \mathrm{pmol})$ into the PPT nucleus and intracerebroventricular administration of UII 
(0.6 nmol) dramatically increase the amount of REM sleep in rats. Relative cerebral blood flow was unaffected when UII was administered into the PPT nucleus. Furthermore, using whole-cell recordings, we demonstrate that UII selectively excites mesopontine cholinergic PPT neurons by activating a slow inward current. Collectively, our data strongly suggest that UII can function to modulate REM sleep by enhancing the excitability of mesopontine cholinergic neurons, independent of its effects on the cerebral vasculature.

\section{Materials and Methods}

Animals and surgery. Thirty-two adult male Sprague Dawley rats (250-300 g) were implanted under halothane anesthesia (1-2\%), with a standard set of stainless-steel screw electrodes for chronic sleep recordings. The electroencephalogram (EEG) was recorded from electrodes placed on the frontal (two electrodes) and parietal (two electrodes) bone over the hippocampus [anteroposterior (AP), -2.46; mediolateral (ML), \pm 2.0 ]. A fifth EEG electrode was placed over the cerebellum to ground the animal and to reduce signal artifacts. Two wire electrodes were inserted in the neck musculature to record postural tone through electromyographic (EMG) activity. Insulated leads from the EEG and EMG electrodes were then soldered to a miniconnector that was cemented to the skull with dental acrylic. In addition to the EEG and EMG electrodes, a chronic guide stainless-steel cannula was implanted aseptically into the right lateral ventricle of 10 rats. The guide cannula was placed according to the stereotaxic coordinates of the atlas of Paxinos and Watson (1986) [AP, -0.34 ; ML, + 1.4; dorsoventral (DV), +2.8]. A second group of rats $(n=10)$ was implanted bilaterally in the pars dissipatus region of the PPT nucleus (AP, $-8.0, \mathrm{ML}, \pm 2.0 ; \mathrm{DV},-5.7$ ) (Paxinos and Watson, 1986). A third cohort of rats $(n=8)$ was implanted bilaterally with guide cannulas into the PPT pars compacta (PPT-pc) region $(\mathrm{AP},-8.3$; $\mathrm{ML}, \pm 2.0 ; \mathrm{DV}$, -7.0 ), which has a dense population of cholinergic neurons and is the region in which the electrophysiological recordings were conducted. To evaluate the specificity of effects of UII on PPT cholinergic neurons, four rats were implanted with a chronic guide stainless-steel cannula into the right locus ceruleus (LC) (AP, -12.35 ; $\mathrm{ML},+1.1$; $\mathrm{DV},+7.45$, using a posterior angle of $20^{\circ}$ from vertical).

After surgical implantation and appropriate wound closure, rats were housed in individual Plexiglas recording cages placed in environmentally controlled chambers (Tech/Serv model EPC-010; BRS/LVE, Laurel, MD). The animals were allowed sufficient time to recover before the study. During anesthetic recovery, animals were observed in a clean single cage, and their normal righting capability and locomotion were monitored. The ambient temperature was maintained at $25^{\circ} \mathrm{C} \pm 1$, and a $12 \mathrm{~h} \mathrm{light/dark}$ cycle was maintained throughout the $10 \mathrm{~d}$ recovery period and the subsequent experiment period. Food and water were available ad libitum.

Sleep recordings. Rats were housed in individual recording cages that were maintained at the same temperature and light/dark cycle described
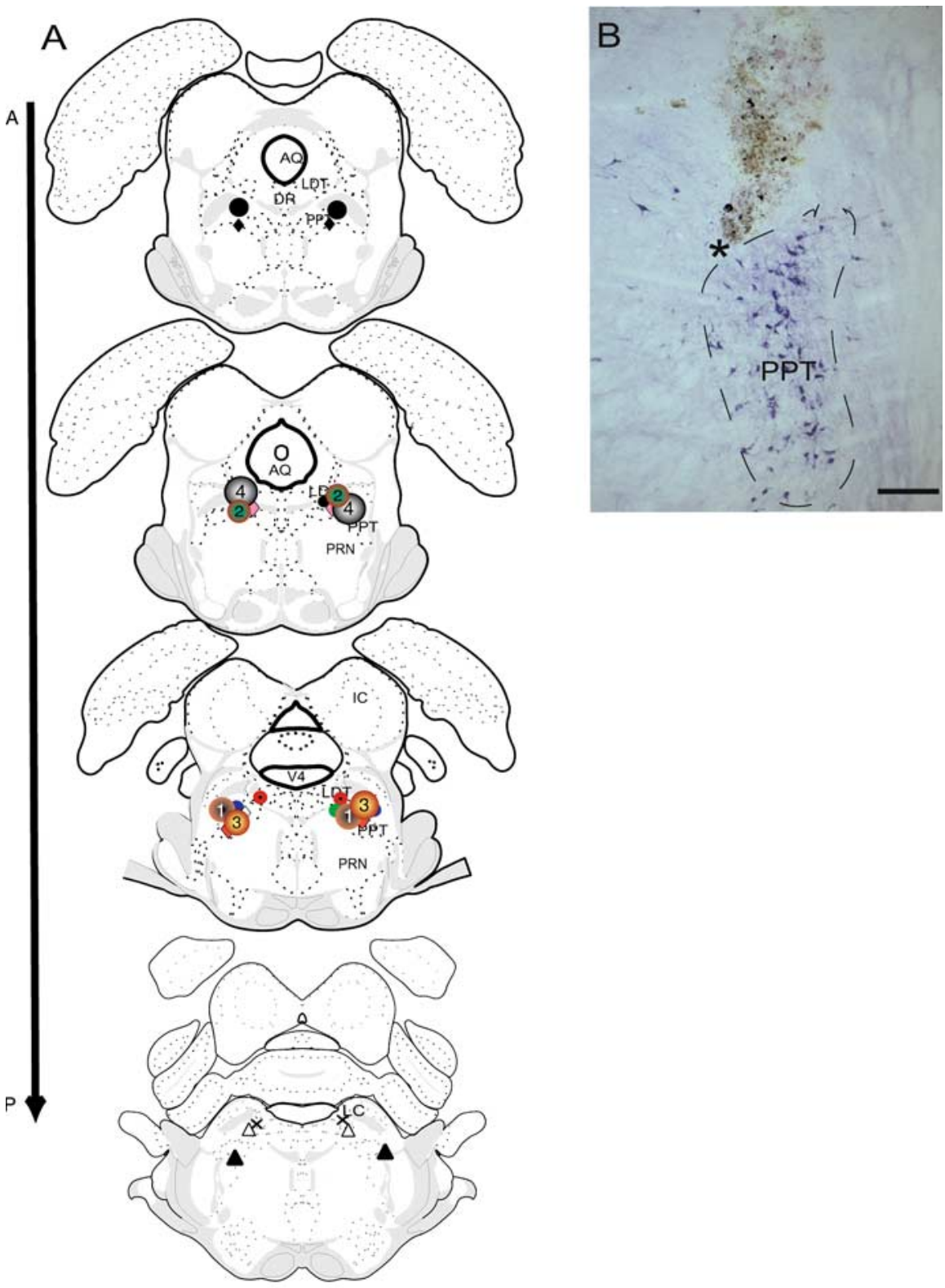

Figure 1. Schematic representation of UII injection sites. $\boldsymbol{A}$, Drawings of coronal sections at three different levels of the brainstem (Swanson, 1992). The circles correspond to the positive sites (at least one site is located in the PPT) for which significant changes in REM sleep were observed after bilateral infusion of the $0.6 \mathrm{pmol}$ of UII. For each rat, the bilateral sites are represented by a colored circle. The rats injected in the $\mathrm{LC}$ are represented by $\times$ and a triangle. The rats treated with UII and its antagonist are represented by diamonds. Four animals received injections of biotinylated UII (numbered 1-4), and the spread of biotinylated peptide was analyzed $2 \mathrm{~h}$ after injection, using streptavidin peroxidase. All animals considered in the analysis had their injection sites verified anatomically. PRN, Pontine reticular nucleus; DR, dorsal raphe; $A Q$, aqueduct; $V 4$, fourth ventricle; IC, inferior colliculus. $\boldsymbol{B}$, Micrograph of one of the injection sites in the PPT. The asterisk marks the tip of the injector, next to cholinergic neurons in the PPT nucleus stained for NADPH diaphorase. Scale bar, $75 \mu \mathrm{m}$

above. To record sleep-wake states, rats were connected to commutators with flexible cables, allowing their unrestricted movement within the cage, and they were habituated to the recording cages for $96 \mathrm{~h}$. The EEG and EMG signals were amplified in a Grass Instruments (Quincy, MA) model 7D polygraph, filtered in a frequency range of $0.30-75 \mathrm{~Hz}$ and sampled at $256 \mathrm{~Hz}$. The EEG and electromyogram were displayed on a computer monitor and stored with a resolution of $128 \mathrm{~Hz}$ for off-line scoring of sleep-wake states and spectral analysis, using software supplied by Kissei Comtec (Irvine, CA). The EEG and electromyogram were recorded over $6 \mathrm{~h}$. The recording chambers contained a mini video camera for continuously observing animal behavior during the recording sessions. 
Experimental protocol. Six days after surgery, the patency and free drainage of the guide cannula were assessed in animals intracerebroventricularly implanted by microinjection of $5.0 \mu$ l of pyrogen-free isotonic saline (PFS; Abbott Laboratories, North Chicago, IL) over a 5 min period. The patency for cannulas implanted into the PPT nucleus was assessed by microinjection of $0.5 \mu \mathrm{l}$ of PFS over a $10 \mathrm{~min}$ period. Procedures for minimizing potential contamination by extraneous pyrogens were used for all drug solutions and vehicles.

The sleep recordings on rats implanted with an intracerebroventricular cannula began $5 \mathrm{~h}$ after the onset of the light period [circadian time (CT) 5; CT0, lights on] observing the following schedule: on day 1, rats were injected intracerebroventricularly with $5.0 \mu \mathrm{l}$ of PFS vehicle at CT5, and recordings were continued for $6 \mathrm{~h}$; on day 3, the same rats were challenged at CT5 with $0.6 \mathrm{nmol}$ of UII in $5.0 \mu \mathrm{l}$ of vehicle. Injections were made over a $5 \mathrm{~min}$ period. UII was obtained from Bachem (Torrance, CA).

The cohort of rats implanted with cannulas in the PPT nucleus pars dissipatus and four rats implanted with cannulas into the PPT-pc were recorded according to the following schedule: on the first day, rats received a bilateral injection of $0.5 \mu \mathrm{l}$ of PFS vehicle into the PPT nucleus at CT5, and recordings were continued for $6 \mathrm{~h}$; on the third and fifth days, rats were injected bilaterally at CT5 into the PPT nucleus with 0.6 and 6.0 pmol, respectively, of UII in $0.5 \mu$ l of vehicle.

The other four rats implanted with cannulas into the PPT-pc received, on day 1 , a bilateral injection of $0.3 \mu \mathrm{l}$ of PFS. On day $3,3 \mathrm{ng}$ of Cpa-DCys-Pal-D-Trp-Lys-Val-Cys-Cpa- $\mathrm{NH}_{2}$ (SB-710411), a UII receptor antagonist (Behm et al., 2002, 2004), was injected and followed 30 min later by a 0.6 pmol injection of UII. On day 5, animals were treated with $3 \mathrm{ng}$ of SB-710411.

For both intracerebroventricular and microinjection experiments, UII treatments were done at CT5, and $6 \mathrm{~h}$ recordings were obtained. We skipped $1 \mathrm{~d}$ between treatments to ensure that the effects of the previous treatment had disappeared. All microinjections were made over a $10 \mathrm{~min}$ period.

To determine the spread of intracellular injections, four animals were injected with $0.2 \mu \mathrm{l}$ of biotinylated UII (Phoenix Pharmaceuticals, Belmont, CA) into the PPT. The rats were killed $2 \mathrm{~h}$ after injection under deep anesthesia with $5 \%$ halothane by intracardial perfusion with $4 \%$ paraformaldehyde in phosphate buffer. The brain was removed, sliced, and stained for NADPH diaphorase to visualize the PPT nucleus. The injected peptide was visualized with $\mathrm{ABC}$ peroxidase and $\mathrm{DAB} / \mathrm{H}_{2} \mathrm{O}_{2}$. In all instances, the biotinylated peptide could be detected in the PPT area (see Fig. 1).

Rats implanted for LC injections received, on day 1, a microinjection of PFS, whereas on day 3 they were challenged with $6.0 \mathrm{pmol}$ of UII. Injection time and recording conditions were the same as those for other groups.

Infusion sites were verified histologically in $25 \mu \mathrm{m}$ frontal-brain sections stained with cresyl violet and methylene blue. A set of sections was stained for NADPH diaphorase, which stains cholinergic neurons in the LDT/PPT (Vincent and Kimura, 1992), to verify that the injection site was in close proximity to the PPT.

Sleep and EEG data analysis. The polygraphic data were classified in $15 \mathrm{~s}$ epochs as the following states of vigilance: wakefulness (W), slowwave sleep 1 (SWS1), SWS2, and REM sleep, as described previously (Lerner et al., 1994; Cravatt et al., 1995). Percentage of total time spent in W, SWS1, SWS2, and REM sleep per hour was calculated. The latency to the onset of the first SWS2 and REM sleep episodes and the frequency and duration of the individual SWSs and REM sleep episodes were also calculated. In addition to standard sleep analysis, EEG spectral analyses in the different sleep-wake stages were performed by Fourier fast transformation analysis using $4 \mathrm{~s}$ epochs, giving $1.0 \mathrm{~Hz}$ bins from 0 to $30 \mathrm{~Hz}$. Each bin was named after its lower limit. The spectral power was divided into wave bands corresponding to $\delta(0.5-4.0 \mathrm{~Hz}), \theta(4.5-12.0 \mathrm{~Hz}), \beta$ $(15.0-20.0 \mathrm{~Hz})$, and $\gamma(30.0-60.0 \mathrm{~Hz})$, averaged over the epoch and divided by bandwidth to give power density for each band. Epochs with artifacts in the polygraph records were discarded. In W, SWS1, SWS2, and REM sleep, only scoring epochs that were both preceded and followed by the same stage were included in the analysis. Because the abso- lute power is quite variable from rat to rat, we normalized the data according to Mendelson and Bergmann (1999) and then compared the mean power in $\delta, \theta, \beta$, and $\gamma$ bands between groups through a repeatedmeasures ANOVA, with Scheffe's $F$ test used for post hoc comparisons. In addition, unpaired, bidirectional $t$ tests were applied to assess the significance of mean EEG power differences in the intracerebroventricular study.

\section{Cortical blood flow}

Surgical preparation. Ten rats were anesthetized with halothane (3-4\%), tracheotomized, and placed into a stereotaxic apparatus. Body temperature was monitored and maintained at $37 \pm 0.1^{\circ} \mathrm{C}$ by a feedbackregulated heating pad. Halothane levels were reduced to $1 \%$ after surgery for the rest of the recording period (typically $4-5 \mathrm{~h}$ ). The skull was exposed, and screws were implanted to record the EEG as described previously. A small craniotomy $(2 \times 2 \mathrm{~mm})$ was performed to expose the cortex, the dura was removed, and the site was superfused with normal saline solution $\left.\left(37^{\circ} \mathrm{C}\right), \mathrm{pH} 7.3-7.4\right)$. CBF was monitored continuously at the site of superfusion with a laser-Doppler (LD) probe $(0.8 \mathrm{~mm}$ tip diameter; Vasamedic, St. Paul, MN) positioned stereotaxically on the parietal cortical surface (stereotaxic coordinates: $4.2 \mathrm{~mm}$ posterior, 2.0 $\mathrm{mm}$ lateral relative to bregma, and $0.5 \mathrm{~mm}$ ventral to dura). For intracerebroventricular injections, a stainless-steel guide cannula was implanted aseptically into the right lateral ventricle (AP, -0.34 ; $\mathrm{ML},+1.4$; DV, +2.8 ), whereas for PPT injections stainless-steel guide cannulas were implanted bilaterally into the PPT nucleus (stereotaxic coordinates: AP, -8.0 ; ML, \pm 2.0 ; DV , +5.7).

Experimental protocol. All experiments started at CT5, observing the following schedule: CBF was measured for $25 \mathrm{~min}$ before and $185 \mathrm{~min}$ after administration of UII in all animals. UII was administered intracerebroventricularly $(n=5)$ at a $0.6 \mathrm{nmol}$ dose $(5 \mu$ l volume $)$ and directly into the PPT nucleus $(n=5)$ at a 0.6 pmol dose ( $0.5 \mu$ l volume).

Monitoring CBF and data analysis. CBF values were observed every 5 min and expressed as a percentage increase relative to the resting baseline level. LD flowmetry monitors relative changes in cerebral blood flow (Dirnagl et al., 1989; Iadecola and Reis, 1990). To minimize confounding effects of anesthesia, the time interval between administration of halothane and testing of hippocampal blood flow was kept consistent. Data were compared by a repeated-measures ANOVA, followed by a Scheffé v́s $F$ test for specific comparisons when indicated.

\section{In vitro studies}

Slice and whole-cell recordings. Brain slices were prepared and whole-cell recordings were conducted as described previously in detail (Burlet et al., 2002). Briefly, $250 \mu \mathrm{m}$ slices containing the PPT were prepared from isofluorane-anesthetized Sprague Dawley rats (postnatal days 12-20; Charles River Laboratories, Wilmington, MA) in ice-cold, carbogenequilibrated, artificial CSF (ACSF), which contained the following (in $\mathrm{mm}$ ): $121 \mathrm{NaCl}, 5 \mathrm{KCl}, 1.2 \mathrm{NaH}_{2} \mathrm{PO}_{4}, 2.7 \mathrm{CaCl}_{2}, 1.2 \mathrm{MgSO}_{4}, 26 \mathrm{NaHCO}_{3}$, and 20 dextrose. Using a fixed-stage microscope (model BX50WI; Olympus, Tokyo, Japan), the boundaries of the PPT were first determined by low-magnification inspection, and then neurons to be recorded were visualized with a cooled CCD video camera (Dage 300T; Dage-MTI, Michigan City, IN) using a $40 \times$ water-immersion objective and infrared differential interference contrast (DIC) optics. The submerged slice recording chamber was perfused at $3-5 \mathrm{ml} / \mathrm{min}$ with room-temperature ACSF. In some experiments, $0.1 \%$ (by weight) BSA (Sigma, St. Louis, $\mathrm{MO}$ ) was included in the ACSF. Rat urotensin II (Phoenix Pharmaceuticals) was dissolved in the perfusate ( $300 \mathrm{~nm})$ just before the experiment and was applied by bath superfusion. In selected bridge-mode recordings aimed at evaluating presynaptic versus postsynaptic contributions to the UII response, tetrodotoxin $(0.5 \mu \mathrm{M})$, DNQX $(15 \mu \mathrm{M})$, APV $(50 \mu \mathrm{M})$, bicuculline $(10 \mu \mathrm{M})$, and strychnine $(2.5 \mu \mathrm{M})$ were included in the superfusion media to block action potentials and fast synaptic potentials.

Giga-seal whole-cell voltage- and current-clamp recordings of PPT neurons were made with pipettes pulled from 1.5-mm-diameter glass capillary tubing (Corning 7052; A\&M Systems, Everett, WA) using an Axopatch 200B amplifier (Molecular Devices, Union City, CA). The pipette solution contained the following (in $\mathrm{mm}$ ): $140 \mathrm{~K}$-gluconate, 4 
MgATP, 10 HEPES, 0.3 NaGTP, and 4 NaCl. Biocytin Alexa Fluor 594 (10 $\mu \mathrm{M}$; Molecular Probes, Eugene, OR) was included in the patch solution for identification of recorded cells. Membrane voltages and currents were controlled and recorded with a computer running pClamp8 software (Molecular Devices). The quality of recordings was assessed by on-line monitoring of access resistance $(<31 \mathrm{M} \Omega)$, input resistance, holding current, and capacitance, and recordings were terminated if the estimated access resistance became unstable or changed by $>20 \%$ between measurements. Recordings were uncompensated for series resistance errors, because the recorded currents and associated voltage errors were small. Electrophysiological signals were filtered at $2 \mathrm{kHz}$ and sampled at $5 \mathrm{kHz}$.

Immunocytochemistry. Cell identification was performed by immunocytochemistry as described previously in detail for brain nitric oxide synthase (bNOS) (Burlet et al., 2002), which is a convenient marker for cholinergic neurons in the LDT and PPT (Vincent and Kimura, 1992). Briefly, after successful removal of the patch pipette from the Alexa Fluor-filled neuron, the slice was fixed in $4 \%$ paraformaldehyde for $1-3 \mathrm{~d}$ at room temperature, cryoprotected by equilibration in $30 \%$ sucrose (0.01 M PBS), and resectioned $(40 \mu \mathrm{m})$ on a freezing microtome. Sections were incubated in rabbit polyclonal anti-bNOS (1:400 in PBS containing $3 \%$ goat serum and $0.3 \%$ Triton X-100 at room temperature; Sigma) and visualized with FITC-conjugated goat anti-rabbit and anti-mouse IgGs (1:50 in PBS; Chemicon, Temecula, CA) to determine whether recorded cells were bNOS-immunoreactive.

Peptides. Rat urotensin II was synthesized by The Scripps Research Institute peptide core facility or purchased from Phoenix Pharmaceuticals or Bachem. Peptide identity was confirmed by mass spectrometry. The UII receptor antagonist SB-710411 (Behm et al., 2002) and biotinylated UII were purchased from Phoenix Pharmaceuticals.

\section{Results}

\section{Effects of local administration of UII into the PPT nucleus}

Effects on the sleep-wake patterns and EEG spectra

We tested the effects on the sleep-wake cycle of local bilateral injections of 0.6 and $6.0 \mathrm{pmol}$ of UII into the PPT nucleus. To locate the specific injection sites, we mapped them histologically according to the atlas of Swanson (1992) (Fig. 1). Administration of $0.6 \mathrm{pmol}$ of UII induced a significant increase in REM sleep of $90.0,59.0$, and $69.8 \%$, respectively, 2,3 , and $4 \mathrm{~h}$ after treatment, $\left(F_{(3,18)}=4.35, p<0.01 ; F_{(3,18)}=4.00, p<0.05\right.$; and $F_{(3,18)}=$ $6.19, p<0.01$, respectively), compared with PFS vehicle. This increase was blocked by pretreatment with SB-710411, a UII receptor antagonist (Behm et al., 2002). The increase in REM sleep was linked to a decrease in the amount of $\mathrm{W}$ during the third and fourth hours after the injection of UII; however, such effects were not significant (Fig. 2). The increase in REM sleep was attributable to a significant increment of $45.3 \%\left(F_{(3,18)}=3.11 ; p<0.05\right)$ in the mean number of REM sleep episodes, whereas the UII receptor antagonist blocked this effect (Table 1). Administration of 0.6 pmol of UII into the PPT nucleus did not produce any significant change in the amount of SWS1 and SWS2. Likewise, no significant changes in any of the stages of vigilance or sleep parameters were observed when animals were treated with 6.0 pmol of UII (Fig. 2). Similar results were observed in rats with cannulas implanted into the PPT-pc, and no significant differences were observed between animals with cannulas implanted into the PPT pars dissipatus and those with cannulas implanted into the PPT-pc (data not shown).

UII administration $(0.6 \mathrm{pmol})$ led to marked changes in the EEG power density in some frequency bands compared with saline and $6.0 \mathrm{pmol}$ of UII. An increase in the power was observed both in $\gamma\left(F_{(2,2900)}=17.10 ; p<0.01\right)$ and $\theta\left(F_{(2,2900)}=10.58 ; p<\right.$ $0.01)$ frequency bands during $W$ and REM sleep, respectively, whereas no significant changes were observed with 6.0 pmol of
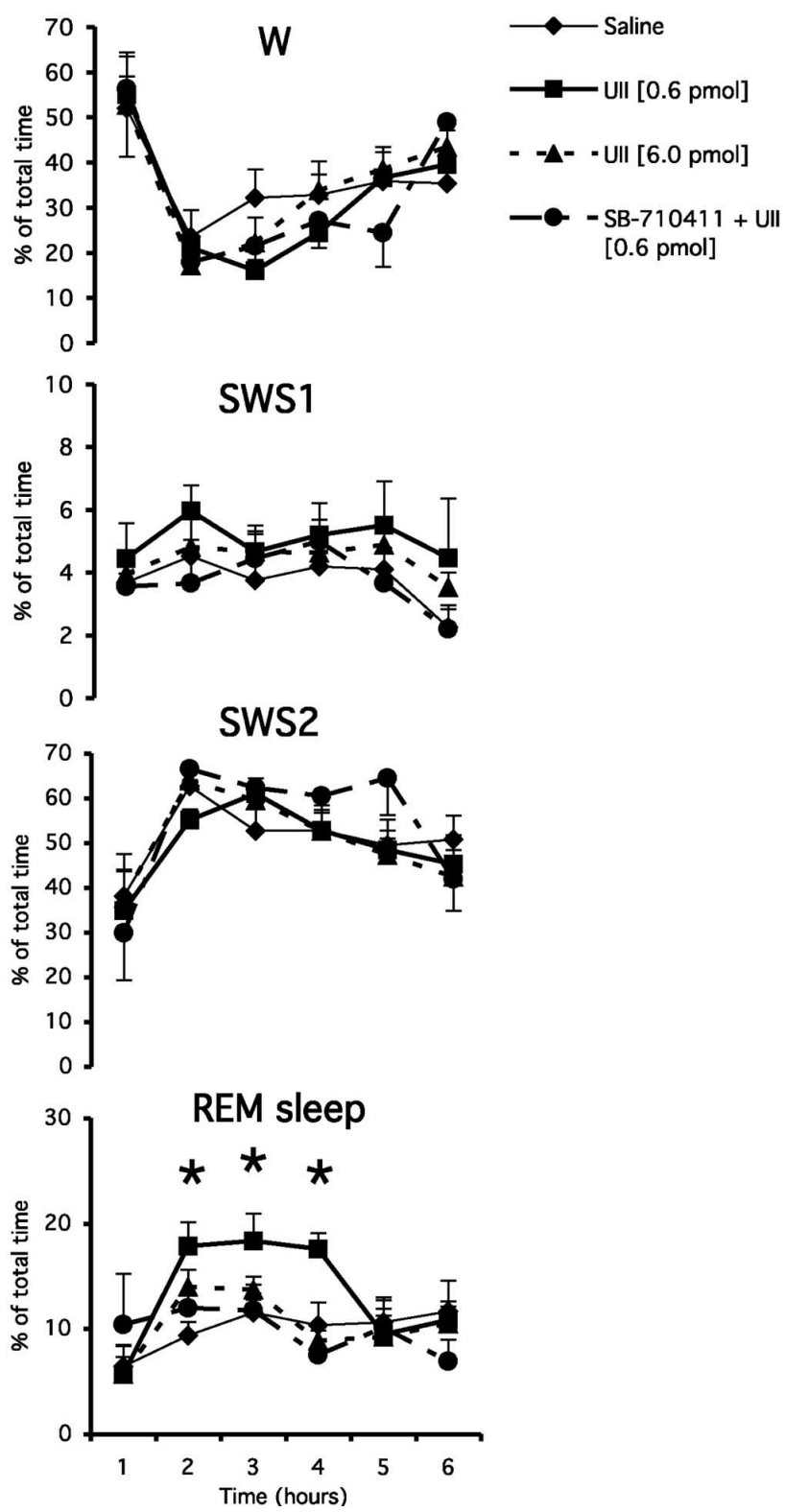

Figure 2. Effects of bilateral administration of Ull into the PPT nucleus on the amount of W, SWS1, SWS2, and REM sleep across recording time. Values (mean \pm SEM; $n=6$ rats for each UII-treated group, and $n=4$ for the group pretreated with the antagonist for UII receptors) represent the relative amount of the vigilance states, expressed as a percentage of total time of recording. Significant group effects of UII were identified using one-way ANOVA and Sheffé's $F$ test and are indicated by asterisks (for values, see Results). Error bars represent SEM.

UII. These increases in EEG power density were blocked by the SB-710411 (Fig. 3).

Administration of UII into the LC produced no significant change in the amount of W (125.94 $\pm 12.58 \mathrm{~min})$, SWS1 (9.81 \pm $1.0 \mathrm{~min})$, SWS2 (197.19 $\pm 9.51 \mathrm{~min})$, and REM sleep (27.12 \pm $5.45 \mathrm{~min}$ ) compared with saline administration (W, $111.63 \pm$ 3.52; SWS1, $10.38 \pm 2.03$; SWS2, $200.25 \pm 4.31$; REM sleep, $37.87 \pm 3.59 \mathrm{~min})$. Significant differences between groups were not observed in the sleep parameters or in the EEG power spectra (data not shown).

Effects on cortical blood flow

Administration of $0.6 \mathrm{pmol}$ of UII into the PPT nucleus did not induce major changes in cortical blood flow compared with 
Table 1. Sleep parameters (mean \pm SEM; in minutes during the $6 \mathrm{hr}$ recording period)

\begin{tabular}{|c|c|c|c|c|c|c|c|c|}
\hline & Sleep latency & REM latency & SWS1-F & SWS1-D & SWS2-F & SWS2-D & REM-F & REM-D \\
\hline Vehicle & $23.50 \pm 6.89$ & $44.00 \pm 9.56$ & $39.00 \pm 5.38$ & $0.37 \pm 0.06$ & $116.66 \pm 15.99$ & $1.70 \pm 0.24$ & $21.66 \pm 2.57$ & $1.66 \pm 0.06$ \\
\hline UII (0.6 pmol) into PPT & $24.33 \pm 7.11$ & $49.50 \pm 9.53$ & $54.00 \pm 7.57$ & $0.31 \pm 0.01$ & $116.16 \pm 10.17$ & $1.57 \pm 0.14$ & $31.50 \pm 2.92^{*}$ & $1.53 \pm 0.11$ \\
\hline UII (6.0 pmol) into PPT & $20.66 \pm 4.18$ & $48.83 \pm 4.73$ & $49.00 \pm 2.79$ & $0.31 \pm 0.01$ & $124.33 \pm 5.30$ & $1.47 \pm 0.13$ & $25.33 \pm 2.30$ & $1.47 \pm 0.05$ \\
\hline SB-710411 (3 ng) plus UII (0.6 pmol) into PPT & $15.81 \pm 3.21$ & $33.56 \pm 13.02$ & $46.00 \pm 2.48$ & $0.28 \pm 0.01$ & $102.25 \pm 10.78$ & $1.95 \pm 0.31$ & $21.50 \pm 2.78$ & $1.63 \pm 0.10$ \\
\hline Vehicle & $20.20 \pm 2.93$ & $41.41 \pm 5.80$ & $55.83 \pm 11.75$ & $0.31 \pm 0.01$ & $122.66 \pm 5.60$ & $1.38 \pm 0.12$ & $26.00 \pm 3.02$ & $1.27 \pm 0.12$ \\
\hline UII (0.6 nmol, i.c.v.) & $24.37 \pm 6.07$ & $31.50 \pm 6.41$ & $39.66 \pm 1.45$ & $0.28 \pm 0.01$ & $129.16 \pm 7.98$ & $1.20 \pm 0.06$ & $48.16 \pm 3.77^{*}$ & $1.21 \pm 0.06$ \\
\hline
\end{tabular}

D, Duration; $F$, frequency. ${ }^{*} p<0.05$.
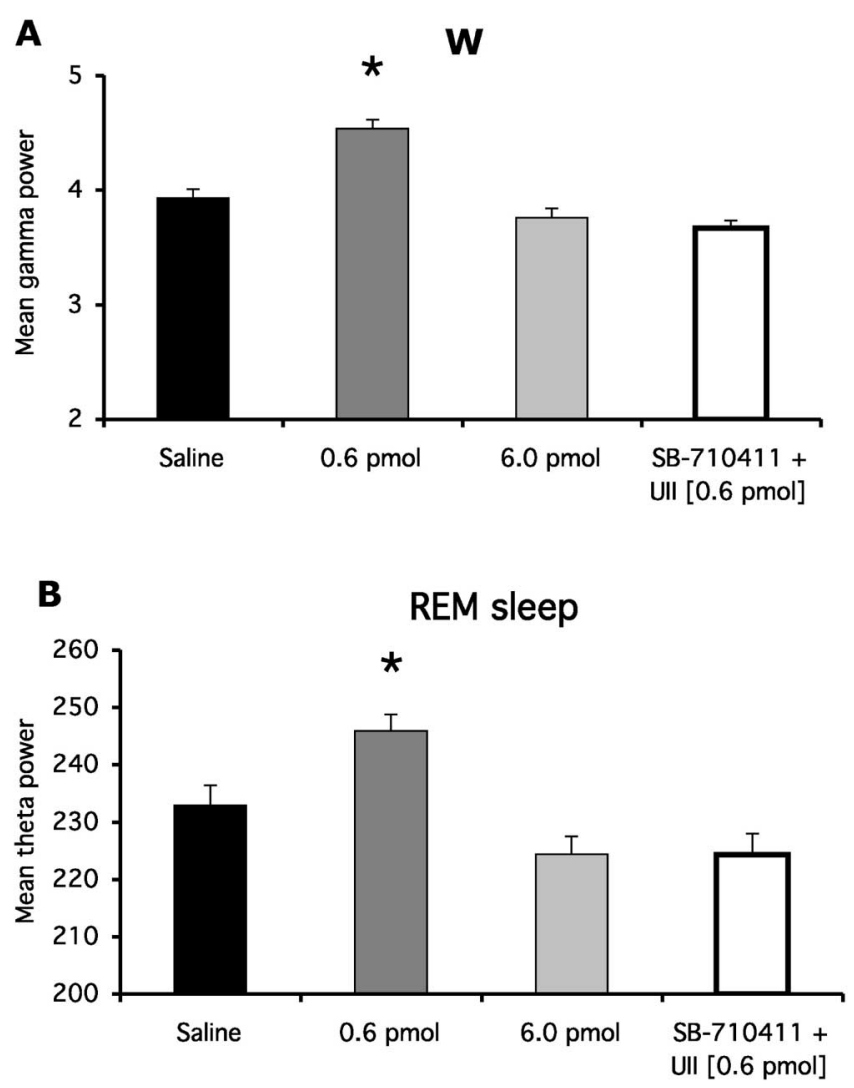

Figure 3. Effects of bilateral injection of UII into the PPT nucleus on EEG power spectra. Administration of $0.6 \mathrm{pmol}$ of Ull induced a significant increase in the $\gamma(\boldsymbol{A} ; p<0.01)$ and $\theta(\boldsymbol{B}$; $p<0.01$ ) power compared with saline and $6.0 \mathrm{pmol}$ of $\mathrm{UII}$, indicating that microinjection of UIII into the PPT nucleus induces cortical activation. Note that these effects were blocked by pretreatment with the UII receptor antagonist SB-710411. Error bars represent mean values ( \pm SEM; $n=6$ rats for each Ull-treated group, and $n=4$ for the group pretreated with SB-710411). Significant effects of UIII compared with saline group are indicated by asterisks and were obtained using one-way ANOVA and a Sheffé's $F$ test.

saline, and only a slight increase $(7.4 \%)$ was observed 30 min after injection $\left(F_{(1,8)}=5.73 ; p<0.05\right)$ (Fig. $\left.4 A\right)$.

\section{Effects of intracerebroventricular administration of UII}

Effects on the sleep-wake patterns and EEG spectra

To test whether intracerebroventricular administration of UII induces changes in sleep-wake patterns, we challenged the animals with $0.6 \mathrm{nmol}$ of UII. UII induced a significant increase of $37.0 \%$ in the total amount of $\mathrm{W}$ during the first hour after treatment, compared with saline administration $\left(F_{(1,10)}=5.574 ; p<\right.$ $0.05)$. The amount of SWS 2 was significantly decreased 1 and $2 \mathrm{~h}$ after UII injection (53.3 and $20.0 \%$, respectively; $F_{(1,10)}=12.84$, $p<0.01 ; F_{(1,10)}=14.68, p<0.01$, respectively), compared with saline administration. Likewise, intracerebroventricular administration of $0.6 \mathrm{nmol}$ of UII induced a significant increase of 78.7,
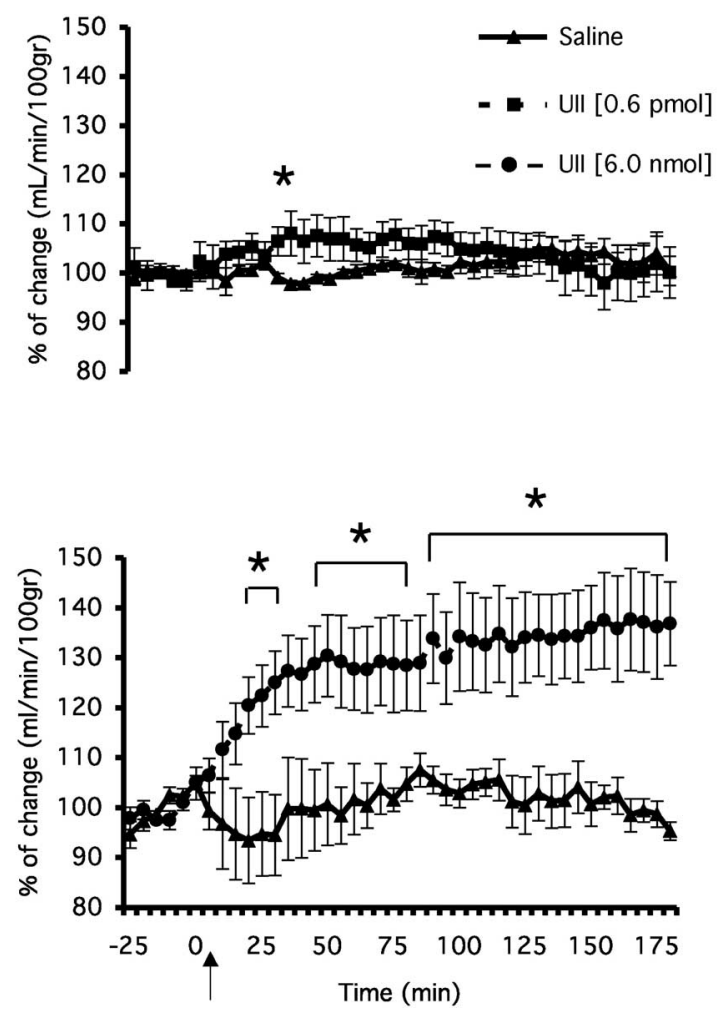

B

Figure 4. Effects of Ull on cortical blood flow. $A$, The effects of a bilateral injection of $0.6 \mathrm{pmol}$ of UII into the PPT nucleus. $\boldsymbol{B}$, The effects of an intracerebroventricular injection of $0.6 \mathrm{nmol}$ of UII. Each point represents mean values ( \pm SEM; $n=5$ rats per group) recorded every 5 min. Values are expressed as the percentage of the values for the same rat before UII treatment (100\%). The arrow indicates the time of injection of UII. Significant effects of UII were identified using one-way ANOVA and a Sheffé's $F$ test and are indicated by asterisks (for values, see Results). Error bars represent SEM.

108.1 , and $108.8 \%$ in the amount of REM sleep 2, 3, and $5 \mathrm{~h}$ after treatment, respectively $\left(F_{(1,10)}=24.68, p<0.001 ; F_{(1,10)}=8.21\right.$, $p<0.01$; and $F_{(1,10)}=11.19, p<0.01$, respectively) compared with saline injections (Fig. 5). No significant differences were observed in the amount of SWS1 after the administration of UII. The effects on REM sleep after intracerebroventricular administration of UII were attributable to an increase of $85.2 \%$ in the mean number of REM sleep episodes $\left(F_{(1,10)}=21.03 ; p<0.001\right)$ compared with saline, without significant changes in other sleep parameters measured in this study (Table 1).

EEG power spectra analysis in the different sleep-wake stages showed a significant increase in power both in $\theta(p<0.01)$ and $\gamma$ $(p<0.01)$ bands during $\mathrm{W}$, as well as an increase in $\gamma$ during REM sleep $(p<0.01)$ after the administration of $0.6 \mathrm{nmol}$ of UII compared with saline (Fig. 6). The mean power for $\delta$ was reduced in SWS2 after administration of UII; however, this reduction did not reach significant values. 

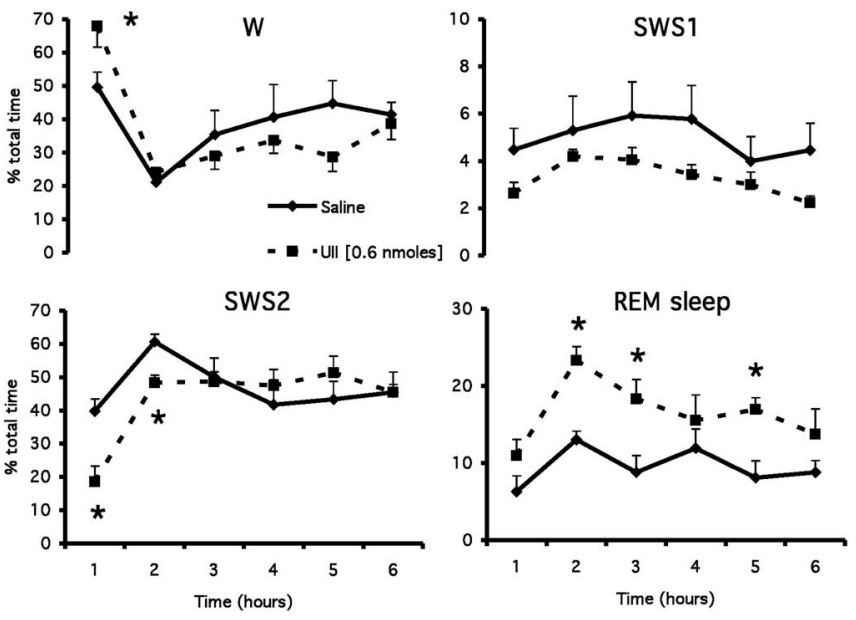

Figure 5. Effects of intracerebroventricular injection of UII into the PPT nucleus on the amount of W, SWS1, SWS2, and REM sleep across recording time. Values (mean \pm SEM; $n=6$ rats per group) represent the amount of the states of vigilance, expressed as a percentage of total time of recording. Significant effects of UII compared with the saline group were obtained using an unpaired bidirectional $t$ test and are indicated by asterisks (for values, see Results). Error bars represent SEM.
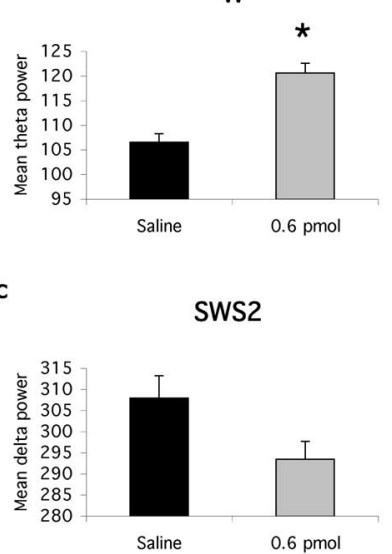
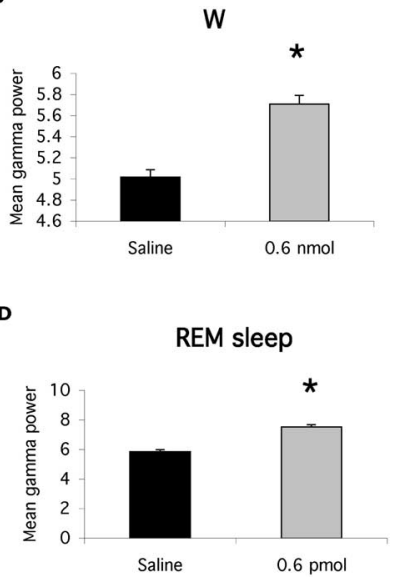

Figure 6. Effects of intracerebroventricular injection of $0.6 \mathrm{nmol}$ of UII on the EEG power. UII induced a significant increase in the mean power of $\theta(\boldsymbol{A} ; p<0.01)$ and $\gamma(\boldsymbol{B} ; p<0.01)$ bands during $\mathrm{W}$, as well as a significant increase in $\gamma$ during REM sleep $(\boldsymbol{D} ; p<0.01)$ compared with saline, whereas UII reduced the $\delta$ power in SWS2. However, this reduction did not reach significant levels $(\boldsymbol{C})$. These results confirm the role of UII in cortical activation. Bars represent mean values ( $\pm S E M ; n=6$ rats per group). Significant effects of UII compared with the saline group were identified using a $t$ test and are indicated by asterisks.

Effects on cortical blood flow

Administration of $0.6 \mathrm{nmol}$ of UII (intracerebroventricularly) resulted in a pronounced increase in cortical blood flow compared with saline treatment $\left(F_{(1,8)}=5.73 ; p<0.05\right)$, starting 20 min after injection. The most prominent increase was observed between 90 and 180 min after UII treatment, when the blood flow values increased $\sim 30 \%$ compared with saline (Fig. $4 B$ ).

\section{Whole-cell recordings}

To investigate the actions of UII on mesopontine cholinergic neurons near the effective injection sites, whole-cell recordings were obtained from 15 neurons in the rat PPT nucleus (mean input resistance, $287 \pm 43 \mathrm{M} \Omega$; mean capacitance, $65 \pm 5.0 \mathrm{pF}$ ). Under whole-cell voltage-clamp conditions (holding potential, $-60 \mathrm{mV}$ ), $300 \mathrm{~nm}$ UII evoked a slow inward shift of the holding current $(-11.8 \pm 1.9 \mathrm{pA}$; mean \pm SEM) (Fig. $7 A)$ in 11 of 15 PPT neurons, which was accompanied by a $35 \%$ increase in input resistance [from $241 \pm 28$ to $324 \pm 36 \mathrm{M} \Omega( \pm$ SEM $)$ ]. These actions were specific for cholinergic neurons ( $p=0.009$; Fisher's test), because UII evoked such an inward current in 11 of 12 bNOS-immunopositive neurons, whereas UII failed to have an effect on three of three bNOS-immunonegative PPT neurons (Fig. 7B).

As expected, current-clamp recordings revealed that UII produced membrane depolarization and an increase in firing of PPT neurons ( $n=6$ of 8 ; 4 of 6 confirmed bNOS-immunopositive). An example of the ability of UII to alter spike discharge rate is shown in Figure $8 \mathrm{~A}$, in which the UII-evoked depolarization drives a quiescent neuron into prolonged repetitive firing. The amplitude of the membrane depolarization elicited by UII was estimated to be $5.7 \pm 1.2 \mathrm{mV}$ in neurons held at subthreshold potentials $(n=3)$. After blockade of action potentials and fast synaptic activity with TTX, APV, DNQX, strychnine, and bicuculline, UII still evoked comparable depolarizations $(7.0 \pm 0.6$ $\mathrm{mV} ; n=3$; all bNOS-immunopositive) (for sample response, see Fig. $8 \mathrm{~B}$ ), suggesting a postsynaptic site of action. As observed in voltage-clamp recordings, membrane input resistance also increased during these UII-evoked depolarizations (Fig. 8C). Finally, in the time frame of our recording experiments, a second application of UII only produced responses that were greatly attenuated, consistent with desensitization. Collectively, data from whole-cell recordings strongly suggest that UII selectively and directly excites cholinergic PPT neurons by activating a slow inward current.

\section{Discussion}

We hypothesized that the UII system could be involved in the regulation of REM sleep based on the fact that UII receptors colocalize with ChAT in the mesopontine tegmental area, including PPT and LDT nuclei (Clark et al., 2001). Our results show that both local PPT and intracerebroventricular administration of low doses of UII dramatically increased the total time of REM sleep in rats. This effect could be accounted for by a significant increase in the number of REM episodes. Likewise, our results showed that UII selectively excites PPT cholinergic neurons at their resting membrane potential by activating a slow inward current (Fig. 7), supporting the hypothesis that increments in REM sleep caused by UII could be a result of neuroexcitation of mesopontine cholinergic neurons. In addition, the absence of a UII-related increase in REM sleep in both animals pretreated with SB-710411 and rats treated with UII in the LC strongly suggests that UII regulates REM sleep through activation of UII receptors located in PPT neurons and that its effects are not mediated through metabolic products.

Both the LDT and PPT send cholinergic projections to the REM sleep, generating neurons located in the pontine reticular formation (Mitani et al., 1988). These inputs, when stimulated, produce EPSPs in the pontine reticular formation neurons (Imon et al., 1996; Homma et al., 2002). Because of the stimulatory effect of UII on PPT neurons, it is likely that UII induces acetylcholine release in the pontine reticular formation and induces REM sleep. The magnitude of the increase in REM recorded in this study is at least as large as that recorded when carbachol is injected into the oral pontine reticular nucleus of the rat, which induces an increase in REM sleep episodes with no change in episode length or latency to REM onset (Bourgin et al., 1995). Microinjection of carbachol into the medial gigantocellular tegmental field produces an increase in $\mathrm{ACh}$ release for $7 \mathrm{~h}$ that has been related to 

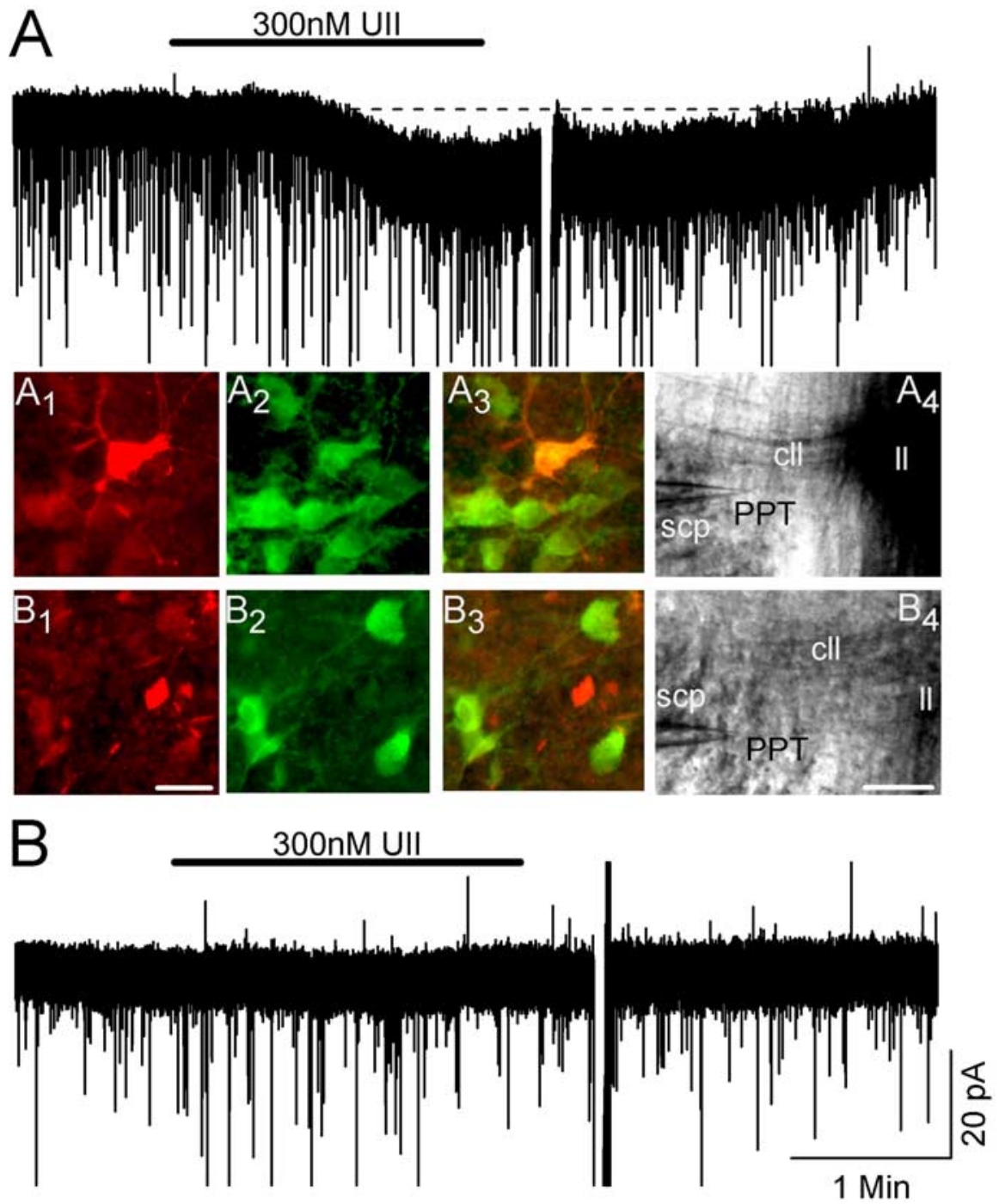

Figure 7. Ull selectively excites bNOS-immunopositive mesopontine cholinergic neurons by evoking an inward current. $\boldsymbol{A}$, Top Membrane current from a PPT cell clamped near resting membrane potential ( $-60 \mathrm{mV}$ ) before and after bath superfusion of 300 nм UII. The slow inward current was observed in bNOS-immunopositive neurons. $A_{1}$, The neuron from which the membrane current was obtained (Alexa 594; red). $\boldsymbol{A}_{2}$, The same field, with cholinergic neurons visualized by bNOS immunocytochemistry (FITC; green). $A_{3}$, The two images, merged, revealing that the recorded neuron was immunoreactive for bNOS (yellow). The DIC image in $\boldsymbol{A}_{4}$ was obtained at the end of the recording and identifies the location of the recorded cell at the electrode tip. $\operatorname{scp}$, Superior cerebellar peduncle; II, lateral lemniscus; cll, commissural fibers of the II. $\boldsymbol{B}$, Bottom, Membrane current of a bNOSimmunonegative PPT neuron was unchanged after superfusion of UII. $\boldsymbol{B}_{\boldsymbol{1}}-\boldsymbol{B}_{4}$ show that the recorded neuron was bNOSimmunonegative and also show its location (imaging is as described for $\boldsymbol{A}_{\boldsymbol{1}}-\boldsymbol{A}_{4}$ ). Scale bars (for $\boldsymbol{A}$ and $\boldsymbol{B}$ ): $\boldsymbol{B}_{1}, 50 \mu \mathrm{m}$ (for immunofluorescent images); $\boldsymbol{B}_{4}, 200 \mu \mathrm{m}$ (for DIC images). Breaks in current traces after Ull application result from voltage jumps to assess conductance changes.

PPT/LDT activation (Lydic et al., 1991; Lydic and Baghdoyan, 1993), whereas glutamatergic stimulation of PPT increases REM sleep up to $6 \mathrm{~h}$ after injection (Datta et al., 2001). These results mirror the parameters of the UII-induced increase in REM state. The slow onset of the UII-induced increase in REM sleep in our studies could be caused by the slow diffusion rate of UII in the brain parenchyma, as described previously for hypocretin (Hcrt) (Bourgin et al., 2000).

There are significant differences between the UII-related REM sleep effects and the activation of PPT neurons by microinjection of excitatory amino acids such as L-glutamate. Glutamatergic stimulation of the PPT in rats reduces REM sleep latency and increases REM sleep because of an increase in both duration and number of episodes of REM sleep (Datta et al., 2001). We did not observe significant changes in the latency or duration of REM sleep episodes in the animals treated with UII, suggesting that UII produces a stimulation that is different from the glutamatergic stimulation of the mesopontine cholinergic neurons. It is unlikely that the observed excitation of the PPT nucleus is mediated by glutamate, because the effect of UII was independent of ionotropic blocking of ionotropic glutamate receptors (Fig. 8). Furthermore, breakdown of UII in the doses used here would give rise to a maximal concentration of glutamate of $4 \mu \mathrm{M}$, a concentration that would be ineffective at activating glutamate receptors.

Our results also show that UII affects REM sleep at lower doses and is not effective at higher doses. A possible explanation for this result could be the desensitization of UII responses, as suggested by our whole-cell recordings. This is supported by studies showing that UII receptors located in the aorta of rats desensitize after a double treatment at intervals of $5 \mathrm{~h}$, with different doses of human UII (Camarda et al., 2002). Moreover, UII receptors heterologously expressed in cell lines desensitize after repeated UII treatment (H.-P. Nothacker, personal communication). Additional studies are necessary to establish the dose dependency and the molecular base for the observed phenomenon.

Spectral analysis of cortical EEGs showed a differential EEG activation effect between local PPT and intracerebroventricular treatment of UII in freely moving animals. Thus, injection of UII into the PPT nucleus significantly increases $\gamma$ power in $\mathrm{W}$ and hippocampal theta rhythm during REM sleep, suggesting an activation of the PPT nucleus (Vertes et al., 1993; Kinney et al., 1998; Nowacka et al., 2002). In contrast, intracerebroventricular injection of UII increased high-frequency EEG bands during $\mathrm{W}$ and REM sleep, suggesting UII-induced cortical activation through cholinergic neurons. This is consistent with the fact that activating cholinergic thalamic afferents produces cortical activation by suppressing slow cortical waves between 0.3 and $4.0 \mathrm{~Hz}$ and spindle wave oscillations (11.0-14.0 Hz) (Hu et al., 1989; Curro Dossi et al., 1991; Steriade et al., 1993).

Another key finding of this study was that UII excited bNOSimmunopositive PPT neurons by activating a slow inward current without affecting recorded bNOS-immunonegative neurons, at least at the membrane potentials studied (near rest). This suggests that local application of UII specifically targeted the cholinergic subpopulation of the PPT, as expected from the distribution of UII receptor mRNA (Clark et al., 2001). In unclamped conditions, UII depolarized cholinergic neurons and promoted firing. Blocking action potential discharge and antagonizing fast glutamatergic, GABAergic, and glycinergic neurotransmission 

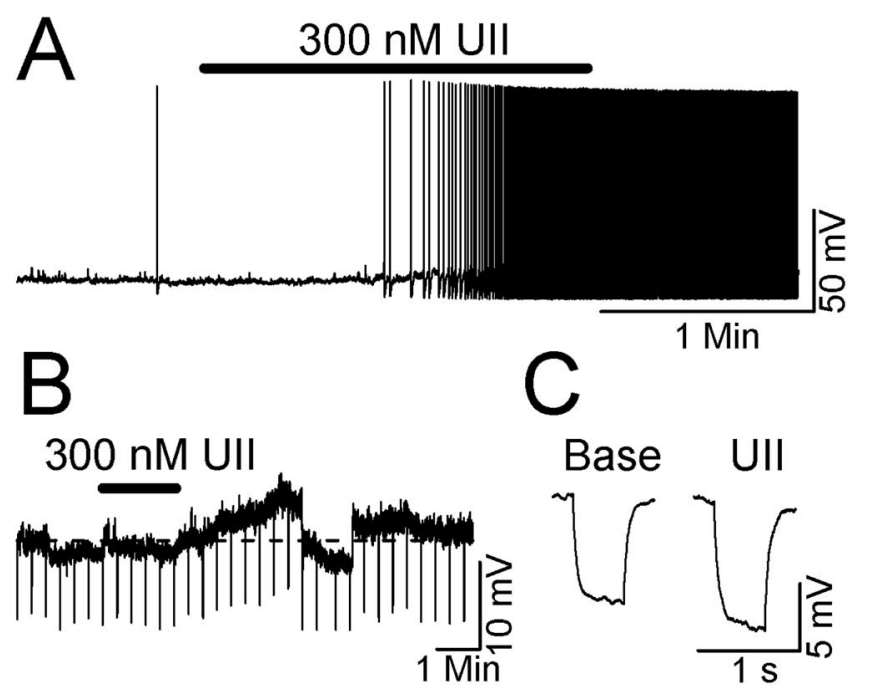

Figure 8. UII depolarizes bNOS-immunopositive cells recorded in current-clamp mode. $\boldsymbol{A}$, This neuron is brought from a state of relative quiescence to rapid, sustained firing by UII application. $\boldsymbol{B}$, The trace shows a bridge-mode recording in the presence of TTX, APV, DNQX, bicuculline, and strychnine. Ull also evokes a depolarization during this synaptic blockade, suggesting a direct postsynaptic mechanism of action. Intermittent hyperpolarizing deflections of the voltage trace show responses to brief current steps ( $500 \mathrm{~ms} ;-25 \mathrm{pA}$ ) to evaluate inputresistance changes. The membrane potential was brought back to baseline levels during the UII effect (70 s hyperpolarizing step) to avoid contamination by voltage-dependent conductance changes. $\boldsymbol{C}$, Average responses to three brief, consecutive current steps $(\boldsymbol{B})$ during baseline (left) and during manual repolarization after UII application (right). Input resistance increased by $24 \%(320-420 \mathrm{M} \Omega$ ) during the Ull effect.

did not attenuate the response to UII. This is consistent with a direct postsynaptic action of UII and, considering our immunochemical findings, implies that the functional UII receptors reside on cholinergic PPT neurons.

We also found that input resistance increased during UIIevoked excitation in both voltage-clamp and bridge-mode recordings. This suggests that UII acts by blocking a hyperpolarizing conductance, which is activated around the resting potential, e.g., a potassium current. Additional work will be necessary to identify the underlying current(s). Nevertheless, this elevation of input resistance should also enhance the effectiveness of synaptic inputs, which may further increase PPT neuron excitation.

The UII-evoked increase in PPT neuron discharge rate will also promote the release of ACh at PPT target structures, such as the thalamus and reticular formation. Indeed, UII may have a general role in promoting ACh release, because, in the periphery, UII stimulates contractions of the ileum by activating myenteric neurons to release ACh (Horie et al., 2003) and acts on frog motoneuron terminals to increase spontaneous ACh release (Brailoiu et al., 2003). Although it is not known whether UII acts at central cholinergic terminals, such an action could also facilitate ACh release and deserves additional investigation.

The slow excitatory action of UII was reminiscent of the excitatory action of Hcrt on mesopontine cholinergic neurons in the LDT (Burlet et al., 2002), although Hcrt activates a broader range of neurons. In the LDT, Hcrt directly activates both cholinergic and noncholinergic neurons, as well as glutamatergic afferents, which synapse on both types of neurons (Burlet et al., 2002). Thus, although Hcrt stimulates the entire reticular activating system (for review, see Siegel, 2004), UII actions appear restricted to the cholinergic component. This difference in cellular sensitivity to the two peptides may have considerable functional impor- tance, because local application of Hcrt enhances waking and suppresses REM sleep (Xi et al., 2001), whereas UII enhances REM sleep.

Previous studies have shown that UII possesses vasoactive properties in fish and mammals (Pearson et al., 1980; Gibson et al., 1986; Ames et al., 1999). We characterized the consequences of UII on regional cerebral blood flow by LD flowmetry (Skarphedinsson et al., 1988; Haberl et al., 1989a,b; Lindsberg et al., 1989; Muir et al., 1992). Although LD flowmetry is not quantitative, it monitors relative changes in regional cerebral blood flow quite accurately (Iadecola, 1997). Our results showed that local PPT administration of UII did not alter the CBF in halothaneanesthetized animals, suggesting that the effect of UII on REM sleep is not dependent on the CBF effects. In contrast, intracerebroventricular administration of UII increased CBF. The cortical hemodynamic effect could be associated with the UII activation of different brain areas involved in cardiovascular regulation (Martin and Haywood, 1992; Kubo et al., 1997; Comer et al., 1998; Haywood et al., 2001). In fact, local injection of UII into the paraventricular nucleus, arcuate nucleus, and noradrenergic cells in the lower part of the medulla induces cardiovascular effects (Lu et al., 2002). Thus, UII may have a neurogenic role in the regulation of cardiovascular physiology, and this may be the cause of the intracerebroventricular application-induced blood flow effects shown here. Despite these findings, an increase in cortical blood flow is not seen with local injections into the PPT. It is, therefore, likely that the blood flow increases are not a result of mesopontine cholinergic activation and would be a result of UII acting on noncholinergic neuronal sites (Lu et al., 2002). However, additional studies are needed to confirm that UII does not induce changes in local blood flow.

Together, the results are consistent with a role for UII in the regulation of REM sleep by activating mesopontine cholinergic neurons directly and independently of the cardiovascular effects of UII.

\section{References}

Ames RS, Sarau HM, Chambers JK, Willette RN, Aiyar NV, Romanic AM, Louden CS, Foley JJ, Sauermelch CF, Coatney RW, Ao Z, Disa J, Holmes SD, Stadel JM, Martin JD, Liu WS, Glover GI, Wilson S, McNulty DE, Ellis CE, et al. (1999) Human urotensin-II is a potent vasoconstrictor and agonist for the orphan receptor GPR14. Nature 401:282-286.

Baghdoyan H, Rodrigo-Angulo M, McCarley RW, Hobson JA (1984) Sitespecific enhancement and suppression of desynchronized sleep signs following cholinergic stimulation of three brainstem regions. Brain Res 306:39-52.

Behm DJ, Herold CL, Ohlstein EH, Knight SD, Dhanak D, Douglas SA (2002) Pharmacological characterization of SB-710411 (Cpa-c[D-CysPal-D-Trp-Lys-Val-Cys]-Cpa-amide), a novel peptidic urotensin-II receptor antagonist. Br J Pharmacol 137:449-458.

Behm DJ, Herold CL, Camarda V, Aiyar NV, Douglas SA (2004) Differential agonistic and antagonistic effects of the urotensin-II ligand SB-710411 at rodent and primate UT receptors. Eur J Pharmacol 492:113-116.

Bohm F, Pernow J (2002) Urotensin II evokes potent vasoconstriction in humans in vivo. Br J Pharmacol 135:25-27.

Bourgin P, Escourrou P, Gaultier C, Adrien J (1995) Induction of rapid eye movement sleep by carbachol infusion into the pontine reticular formation in the rat. NeuroReport 6:532-536.

Bourgin P, Huitron-Resendiz S, Spier AD, Fabre V, Morte B, Criado JR, Sutcliffe JG, Henriksen SJ, de Lecea L (2000) Hypocretin-1 modulates rapid eye movement sleep through activation of locus ceruleus neurons. J Neurosci 20:7760-7765.

Brailoiu E, Brailoiu GC, Miyamoto MD, Dun NJ (2003) The vasoactive peptide urotensin II stimulates spontaneous release from frog motor nerve terminals. Br J Pharmacol 138:1580-1588.

Burlet S, Tyler CJ, Leonard CS (2002) Direct and indirect excitation of lat- 
erodorsal tegmental neurons by hypocretin/orexin peptides: implications for wakefulness and narcolepsy. J Neurosci 22:2862-2872.

Camarda V, Rizzi A, Calo G, Gendron G, Perron SI, Kostenis E, Zamboni P, Mascoli F, Regoli D (2002) Effects of human urotensin II in isolated vessels of various species; comparison with other vasoactive agents. Naunyn Schmiedebergs Arch Pharmacol 365:141-149.

Chartrel N, Conlon JM, Collin F, Braun B, Waugh D, Vallarino M, Vaudry H (1998) Urotensin II in the central nervous system of the frog Rana ridibunda. Biochemical characterization and immunohistochemical localization. Ann NY Acad Sci 839:506-507.

Clark SD, Nothacker HP, Wang Z, Saito Y, Leslie FM, Civelli O (2001) The urotensin II receptor is expressed in the cholinergic mesopontine tegmentum of the rat. Brain Res 923:120-127.

Comer AM, Qi J, Christie DL, Gibbons HM, Lipski J (1998) Noradrenaline transporter expression in the pons and medulla oblongata of the rat: localisation to noradrenergic and some $\mathrm{C} 1$ adrenergic neurones. Brain Res Mol Brain Res 62:65-76.

Conlon JM, Yano K, Waugh D, Hazon N (1996) Distribution and molecular forms of urotensin II and its role in cardiovascular regulation in vertebrates. J Exp Zool 275:226-238.

Conlon JM, Tostivint H, Vaudry H (1997) Somatostatin- and urotensin II-related peptides: molecular diversity and evolutionary perspectives. Regul Pept 69:95-103.

Coulouarn Y, Lihrmann I, Jegou S, Anouar Y, Tostivint H, Beauvillain JC, Conlon JM, Bern HA, Vaudry H (1998) Cloning of the cDNA encoding the urotensin II precursor in frog and human reveals intense expression of the urotensin II gene in motoneurons of the spinal cord. Proc Natl Acad Sci USA 95:15803-15808.

Coulouarn Y, Jegou S, Tostivint H, Vaudry H, Lihrmann I (1999) Cloning, sequence analysis and tissue distribution of the mouse and rat urotensin II precursors. FEBS Lett 457:28-32.

Cravatt BF, Prospero-Garcia O, Siuzdak G, Gilula NB, Henriksen SJ, Boger DL, Lerner RA (1995) Chemical characterization of a family of brain lipids that induce sleep. Science 268:1506-1509.

Curro Dossi R, Pare D, Steriade M (1991) Short-lasting nicotinic and longlasting muscarinic depolarizing responses of thalamocortical neurons to stimulation of mesopontine cholinergic nuclei. J Neurophysiol 65:393-406.

Datta S, Spoley EE, Patterson EH (2001) Microinjection of glutamate into the pedunculopontine tegmentum induces REM sleep and wakefulness in the rat. Am J Physiol Regul Integr Comp Physiol 280:R752-R759.

Dirnagl U, Kaplan B, Jacewicz M, Pulsinelli W (1989) Continuous measurement of cerebral cortical blood flow by laser-Doppler flowmetry in a rat stroke model. J Cereb Blood Flow Metab 9:589-596.

Feinberg I, Campbell IG (1999) Adenosine, blood pressure and NREM delta. Sleep 22:7-9.

George R, Haslett WL, Jenden DJ (1964) A cholinergic mechanism in the brainstem reticular formation: induction of paradoxical sleep. Int J Neuropharmacol 72:541-552.

Gibson A, Wallace P, Bern HA (1986) Cardiovascular effects of urotensin II in anesthetized and pithed rats. Gen Comp Endocrinol 64:435-439.

Haberl RL, Heizer ML, Marmarou A, Ellis EF (1989a) Laser-Doppler assessment of brain microcirculation: effect of systemic alterations. Am J Physiol 256:H1247-H1254.

Haberl RL, Heizer ML, Ellis EF (1989b) Laser-Doppler assessment of brain microcirculation: effect of local alterations. Am J Physiol 256:H1255-H1260.

Haywood JR, Mifflin SW, Craig T, Calderon A, Hensler JG, HinojosaLaborde C (2001) Gamma-aminobutyric acid (GABA) - a function and binding in the paraventricular nucleus of the hypothalamus in chronic renal-wrap hypertension. Hypertension 37:614-618.

Homma Y, Skinner RD, Garcia-Rill E (2002) Effects of pedunculopontine nucleus (PPN) stimulation on caudal pontine reticular formation $(\mathrm{PnC})$ neurons in vitro. J Neurophysiol 87:3033-3047.

Horie S, Yasuda S, Tsurumaki Y, Someya A, Saito T, Okuma Y, Nomura Y, Hirabayashi T, Murayama T (2003) Contraction of isolated guinea-pig ileum by urotensin II via activation of ganglionic cholinergic neurons and acetylcholine release. Neuropharmacology 45:1019-1027.

Hu B, Steriade M, Deschenes M (1989) The effects of brainstem peribrachial stimulation on perigeniculate neurons: the blockage of spindle waves. Neuroscience 31:1-12.
Iadecola C (1997) Principles and methods for measurement of cerebral blood flow: experimental methods. In: Primer on cerebrovascular diseases (Welsh KMA, Caplan L, Reis DJ, Siesjo BK, Weir B, eds), pp 34-37. San Diego: Academic.

Iadecola C, Reis DJ (1990) Continuous monitoring of cerebrocortical blood flow during stimulation of the cerebellar fastigial nucleus: a study by laser-Doppler flowmetry. J Cereb Blood Flow Metab 10:608-617.

Imon H, Ito K, Dauphin L, McCarley RW (1996) Electrical stimulation of the cholinergic laterodorsal tegmental nucleus elicits scopolaminesensitive excitatory postsynaptic potentials in medial pontine reticular formation neurons. Neuroscience 74:393-401.

Kinney GG, Vogel GW, Feng P (1998) Brainstem carbachol injections in the urethane anesthetized rat produce hippocampal theta rhythm and cortical desynchronization: a comparison of pedunculopontine tegmental versus nucleus pontis oralis injections. Brain Res 809:307-313.

Kubo T, Yanagihara Y, Yamaguchi H, Fukumori R (1997) Excitatory amino acid receptors in the paraventricular hypothalamic nucleus mediate pressor response induced by carotid body chemoreceptor stimulation in rats. Clin Exp Hypertens 19:1117-1134.

Lerner RA, Siuzdak G, Prospero-Garcia O, Henriksen SJ, Boger DL, Cravatt BF (1994) Cerebrodiene: a brain lipid isolated from sleep-deprived cats. Proc Natl Acad Sci USA 91:9505-9508.

Lindsberg PJ, O’Neill JT, Paakkari IA, Hallenbeck JM, Feuerstein G (1989) Validation of laser-Doppler flowmetry in measurement of spinal cord blood flow. Am J Physiol 257:H674-H680.

Liu Q, Pong SS, Zeng Z, Zhang Q, Howard AD, Williams Jr DL, Davidoff M, Wang R, Austin CP, McDonald TP, Bai C, George SR, Evans JF, Caskey CT (1999) Identification of urotensin II as the endogenous ligand for the orphan G-protein-coupled receptor GPR14. Biochem Biophys Res Commun 266:174-178.

Lu Y, Zou CJ, Huang DW, Tang CS (2002) Cardiovascular effects of urotensin II in different brain areas. Peptides 23:1631-1635.

Lydic R, Baghdoyan HA (1993) Pedunculopontine stimulation alters respiration and increases ACh release in the pontine reticular formation. Am J Physiol 264:R544-554.

Lydic R, Baghdoyan HA, Lorinc Z (1991) Microdialysis of cat pons reveals enhanced acetylcholine release during state-dependent respiratory depression. Am J Physiol 261:R766-R770.

Martin DS, Haywood JR (1992) Sympathetic nervous system activation by glutamate injections into the paraventricular nucleus. Brain Res 577:261-267.

Mendelson WB, Bergmann BM (1999) EEG delta power during sleep in young and old rats. Neurobiol Aging 20:669-673.

Mitani A, Ito K, Hallanger AE, Wainer BH, Kataoka K, McCarley RW (1988) Cholinergic projections from the laterodorsal and pedunculopontine tegmental nuclei to the pontine gigantocellular tegmental field in the cat. Brain Res 451:397-402.

Mori M, Sugo T, Abe M, Shimomura Y, Kurihara M, Kitada C, Kikuchi K, Shintani Y, Kurokawa T, Onda H, Nishimura O, Fujino M (1999) Urotensin II is the endogenous ligand of a G-protein-coupled orphan receptor, SENR (GPR14). Biochem Biophys Res Commun 265:123-129.

Muir JK, Boerschel M, Ellis EF (1992) Continuous monitoring of posttraumatic cerebral blood flow using laser-Doppler flowmetry. J Neurotrauma 9:355-362.

Nothacker HP, Wang Z, McNeill AM, Saito Y, Merten S, O’Dowd B, Duckles SP, Civelli O (1999) Identification of the natural ligand of an orphan G-protein-coupled receptor involved in the regulation of vasoconstriction. Nat Cell Biol 1:383-385.

Nowacka A, Jurkowlaniec E, Trojniar W (2002) Microinjection of procaine into the pedunculopontine tegmental nucleus suppresses hippocampal theta rhythm in urethane-anesthetized rats. Brain Res Bull 58:377-384.

Paxinos GWC, Watson AJ (1986) The rat brain in stereotaxic coordinates. San Diego: Academic.

Pearson D, Shively JE, Clark BR, Geschwind II, Barkley M, Nishioka RS, Bern HA (1980) Urotensin II: a somatostatin-like peptide in the caudal neurosecretory system of fishes. Proc Natl Acad Sci USA 77:5021-5024.

Quattrochi JJ, Mamelak AN, Madison RD, Macklis JD, Hobson JA (1989) Mapping neuronal inputs to REM sleep induction sites with carbacholfluorescent microspheres. Science 245:984-986.

Russell FD, Molenaar P, O’Brien DM (2001) Cardiostimulant effects of urotensin-II in human heart in vitro. Br J Pharmacol 132:5-9. 
Siegel JM (2004) Hypocretin (orexin): role in normal behavior and neuropathology. Annu Rev Psychol 55:125-148.

Skarphedinsson JO, Harding H, Thoren P (1988) Repeated measurements of cerebral blood flow in rats. Comparisons between the hydrogen clearance method and laser Doppler flowmetry. Acta Physiol Scand 134:133-142.

Steriade M, McCarley RW (1990) Brainstem control of wakefulness and sleep. New York: Plenum.

Steriade M, Amzica F, Nunez A (1993) Cholinergic and noradrenergic modulation of the slow (approximately $0.3 \mathrm{~Hz}$ ) oscillation in neocortical cells. J Neurophysiol 70:1385-1400.

Swanson LW (1992) Brain maps: structure of the rat brain. New York: Elsevier. Vanni-Mercier G, Sakai K, Lin JS, Jouvet M (1989) Mapping of cholinocep- tive brainstem structures responsible for the generation of paradoxical sleep in the cat. Arch Ital Biol 127:133-164.

Vertes RP, Colom LV, Fortin WJ, Bland BH (1993) Brainstem sites for the carbachol elicitation of the hippocampal theta rhythm in the rat. Exp Brain Res 96:419-429.

Vincent S, Kimura H (1992) Histochemical mapping of nitric oxide synthase in the rat brain. Neuroscience 46:755-784.

Xi MC, Morales FR, Chase MH (2001) Effects on sleep and wakefulness of the injection of hypocretin-1 (orexin-A) into the laterodorsal tegmental nucleus of the cat. Brain Res 901:259-264.

Yamamoto K, Mamelak AN, Quattrochi JJ, Hobson JA (1990) A cholinoceptive desynchronized sleep induction zone in the anterodorsal pontine tegmentum: locus of the sensitive region. Neuroscience 39:279-293. 